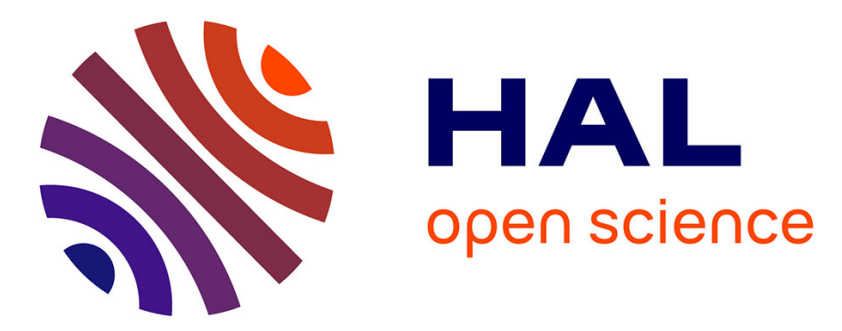

\title{
Carbon flow in the planktonic food web along a gradient of oligotrophy in the Aegean Sea (Mediterranean Sea)
} Ioanna Siokou-Frangou, Micheline Bianchi, Urania Christaki, E. Christou, Antionia Giannakourou, O Gotsis, L Ignatiades, P Pagou, P. Pitta, Stella Psarra, et al.

\section{To cite this version:}

Ioanna Siokou-Frangou, Micheline Bianchi, Urania Christaki, E. Christou, Antionia Giannakourou, et al.. Carbon flow in the planktonic food web along a gradient of oligotrophy in the Aegean Sea (Mediterranean Sea). Journal of Marine Systems, 2002, 33-34, pp.335-353. 10.1016/S0924-7963(02)00065-9 . hal-01780370

\section{HAL Id: hal-01780370 \\ https://hal.science/hal-01780370}

Submitted on 17 Feb 2021

HAL is a multi-disciplinary open access archive for the deposit and dissemination of scientific research documents, whether they are published or not. The documents may come from teaching and research institutions in France or abroad, or from public or private research centers.
L'archive ouverte pluridisciplinaire HAL, est destinée au dépôt et à la diffusion de documents scientifiques de niveau recherche, publiés ou non, émanant des établissements d'enseignement et de recherche français ou étrangers, des laboratoires publics ou privés. 


\title{
Carbon flow in the planktonic food web along a gradient of oligotrophy in the Aegean Sea (Mediterranean Sea)
}

\author{
I. Siokou-Frangou $^{\text {a,* }}$, M. Bianchi ${ }^{\text {b }}$, U. Christaki ${ }^{\text {a }}$, E.D. Christou ${ }^{\text {a }}$, A. Giannakourou ${ }^{\text {a }}$,

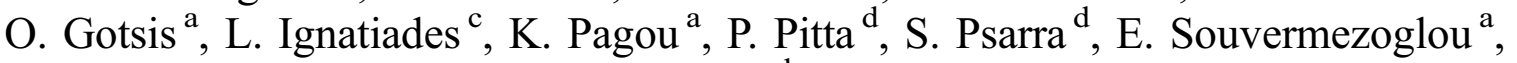 \\ F. Van Wambeke ${ }^{\mathrm{b}}, \mathrm{V}$. Zervakis ${ }^{\mathrm{a}}$

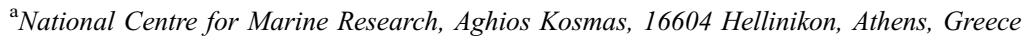 \\ ${ }^{\mathrm{b}}$ Microbiologie Marine, CNRS UMR 6117, Campus de Luminy, 13288 Marseille cedex 9, France \\ "National Research Centre "Demokritos", Athens, Greece \\ ${ }^{\mathrm{d}}$ Institute of Marine Biology of Crete, P.O. Box 2214,71003 Heraklion, Crete, Greece
}

\begin{abstract}
This work is a study of plankton food web structure and carbon flow in March and September 1997 in the Aegean Sea, area of outflow of Black Sea waters in the Mediterranean Sea. Biomass and production of autotrophs were measured by size fraction as well as bacterial biomass and production; furthermore, we studied heterotrophic nanoflagellates (HNAN), ciliates and mesozooplankton biomass, copepod production and grazing impact on phytoplankton. The obtained low values of nutrients and plankton biomass and production confirmed the oligotrophic character of this region. Despite the fact that there was no significant horizontal variability in the spatial distribution of nutrients throughout the study area, the planktonic biomass and production revealed a gradual decrease from the Northeast Aegean (NEA) towards the South Aegean (SA). In the Northeast Aegean, a large part of the fixed carbon was channelled through the microbial food web towards copepods; in contrast there was a low transfer of energy in the South Aegean where the multivorous food web was developed. Throughout the study area, almost $60-70 \%$ of autotrophic biomass and primary production was performed by cells $<3 \mu \mathrm{m}$.
\end{abstract}

Keywords: Plankton; Food web; Carbon flow; Oligotrophy; E. Mediterranean

\section{Introduction}

Carbon flux in the ocean depends mainly on the magnitude of primary production and the biochemical processes within the photic zone, as well as on the

\footnotetext{
* Corresponding author. Tel.: +30-1-9653520; fax: +30-19653522.

E-mail address: isiokou@fl.ncmr.gr (I. Siokou-Frangou).
}

complexity of the pelagic food web, i.e. the relative abundance or biomass of its components and interactions between them. Thus, whatever the productivity level, studies in the photic zone based on simultaneous estimates of the biomass and production of phytoplankton, bacteria, heterotrophic nano- and microplankton and mesozooplankton together are essential for the assessment of the carbon flux (Nielsen et al., 1993; Nielsen and Hansen, 1995; Richardson et al., 1998; Bradford-Grieve et al., 1999). In 
oligotrophic areas, the food web is dominated by minute producers and consumers (e.g., Caron et al., 1999) and most of the carbon flow is through microbial communities (Azam et al., 1983; Sherr and Sherr, 1988; Roman et al., 1995). In the Mediterranean Sea, an oligotrophic area, organic carbon and nutrients are remineralized and recycled efficiently within a complex microbial food web with little energy transfer to the higher trophic levels (Van Wambeke et al., 1996; Turley et al., 2000). Within the Mediterranean Sea, there exists a west-east gradient (Krom et al., 1991; Dolan et al., 1999; Turley et al., 2000): the Eastern Mediterranean has been identified as one of the most oligotrophic areas of the world (Azov, 1986; Krom et al., 1993; Zohary and Robarts, 1998; Souvermezoglou et al., 1992; Mazzocchi et al., 1997).

The Aegean Sea is a distinct sub-system of the Eastern Mediterranean Sea due to its geographical position between the Black Sea and the other seas of the eastern basin (Ionian and Levantine Seas). The bottom topography of the region is characterised by an alternation of plateaux and deep troughs: the Cyclades plateau separates the North from the South Aegean basins, allowing water exchange above 400-m depth. Below $400 \mathrm{~m}$, the deep basins of the North Aegean are filled with very dense water of local origin (Zervakis et al., 2000) and the deep basin of the South Aegean with Cretan Deep Water (Theocharis et al., 1999). The general circulation within the Aegean Sea is cyclonic: highly saline $(S>38.8 \mathrm{psu})$ water of Levantine origin, dominant in the South Aegean, travels northwards along the western coast of Turkey (Theocharis et al., 1999). A surface layer of very light, brackish $(S \sim 30 \mathrm{psu})$ water is formed in the Northeast Aegean by the inflow of modified Black Sea Water (BSW) through the Dardanelles straits; this water mass affects the uppermost $(20-30 \mathrm{~m})$ layer of the North Aegean Sea (Theocharis and Georgopoulos, 1993) and is modified moving westward and southward (Stergiou et al., 1997) by lateral and diapycnal mixing with the waters of Levantine origin. The latter, being diluted to salinities about 38 psu by overlying BSW in the North Aegean, flows southwards along the eastern coast of the Hellenic peninsula, eventually entering the South Aegean and the Cretan Sea. In that region, the water column is largely homogeneous; however, a slightly less saline layer of relatively nutrient-rich Transition Mediterranean
Water occupies intermediate depths $(200-300 \mathrm{~m})$, separating Cretan Intermediate Water and Cretan Deep Water layers (Theocharis et al., 1999).

Although the Aegean Sea has been characterised as an overall oligotrophic environment, it exhibits significant horizontal variability: nutrient concentrations, plankton and benthos abundance as well as fish catch densities have been found higher in the North-Northwest Aegean Sea than in the South-Southeast Aegean Sea (Stergiou et al., 1997). Furthermore, the Black Sea surface outflow in the NE Aegean Sea has been found to be enriched in dissolved organic carbon and dissolved organic nitrogen (Polat and Tugrul, 1996). The South Aegean Sea has been recently characterised as one of the most oligotrophic areas of the Mediterranean Sea (Ignatiades, 1998; Gotsis-Skretas et al., 1999; Van Wambeke et al., 2000; Psarra et al., 2000).

Taking into account the above-mentioned differences within the Aegean Sea, we have examined the hypothesis whether or not they reflect to differences in pelagic food web structure and the carbon flow towards the high levels (fish). The goal of the present study, conducted within the EU project MATER, was to assess the organic carbon partitioning between autotrophic and heterotrophic plankters of different size and to investigate the carbon flow in the photic zone among the different areas of the Aegean Sea.

For this purpose, we have concurrently measured the biomass of autotrophs and heterotrophs, the production of autotrophs, bacteria and copepods, the grazing of heterotrophic nanoflagellates on bacteria and the grazing of copepods on phytoplankton. Furthermore, autotrophic biomass and production were measured by size fractions, since the size of primer producers is of great importance in the characterisation and the functioning of the food web (Legendre and Rassoulzadegan, 1995; Fasham et al., 1999; Nielsen and Hansen, 1999).

\section{Methodology}

\subsection{Study area and sampling}

The strategy was to sample different degrees of oligotrophy (North Aegean versus South Aegean Sea) in two contrasting seasons: in March and September 
when the water column is well mixed and stratified, respectively. Sampling was performed on board the R/ V AEGAEO from 28 March to 2 April 1997 and from 18 to 23 September 1997 at seven stations (N1 to N7) in the North Aegean Sea. In the South Aegean Sea samples were collected at four stations (S1, S2, S6 and S7) from 6 to 9 March 1997 and at five stations (S1, S2, S3, S6 and S7) from 9 to 15 September 1997 (Fig. 1).

\subsection{Hydrographic measurements}

Hydrographic measurements (temperature, pressure, conductivity) were made using a SeaBird Electronics SBE 9/11+CTD-General Oceanics Rosette assembly with 10-1 Niskin bottles. Water samples for inorganic nutrients, phytoplankton biomass and production, bacteria biomass and production, heterotrophic nanoflagellates (HNAN) and ciliates were collected at 2-, 10-, 20-, 30-, 40-, 50-, 75- and 100$\mathrm{m}$ depths.

\subsection{Nutrients}

Samples for the determination of nutrients were collected in 100-ml polyethylene bottles and kept continuously under deep freeze $\left(-20{ }^{\circ} \mathrm{C}\right)$ until analysis in the laboratory by a ALPKEM Flow Solution III, autoanalyser. Phosphate was measured on board, by a Perkin Elmer Lambda 2S UV/VIS Spectrometer. The methods described by Murphy and Riley (1962) for phosphate, Mullin and Riley (1955) for silicate, Shinn (1941) and Strickland and Parsons (1968) for nitrite and nitrate were employed. The precision is estimated at $\pm 0.02 \mu \mathrm{M}$ for phosphate and $\pm 0.1 \mu \mathrm{M}$ for nitrate and silicate.

\subsection{Phytoplankton biomass and production measure- ments}

Water samples (2 1) were size-fractionated by separate filtration on 3.0-, 1.2- and $0.2-\mu \mathrm{m}$ polycarbonate Millipore filters and chlorophyll- $a$ was determined using a TURNER 00-AU-10 fluorometer (Holm-Hansen et al., 1965). Chlorophyll- $a$ concentrations were converted to carbon biomass using the conversion factors applied by Malone et al. (1993) for the Sargasso Sea (oligotrophic area).
Photosynthetic productivity was measured according to the in situ ${ }^{14} \mathrm{C}$ method of Steemann-Nielsen (1952). The samples were dispensed in 250-ml transparent polycarbonate bottles (three light and one dark for each depth) and each one was inoculated with 5 $\mu \mathrm{Ci}{ }^{14} \mathrm{C}-\mathrm{NaHCO}_{3}$ and incubated at the collection depths for $2 \mathrm{~h}$. The incubated samples were then size-fractionated using the same protocol as in chlorophyll- $a$ measurements. Filters were placed in scintillation vials, acidified with $0.5 \mathrm{~N} \mathrm{HCL}$ and counted in a liquid scintillation counter. Daily rates were calculated from hourly rates multiplied by the $12 \mathrm{~h}$ of daylight period during sampling. Euphotic zone (0$100 \mathrm{~m}$ ) integrated phytoplankton biomass and primary production rates were calculated by the trapezoid rule.

Samples for the identification and enumeration of larger phytoplankton cells $(>5 \mu \mathrm{m})$ from selected sampling depths $(2,10,20,50,75,100 \mathrm{~m})$ were preserved in alkaline Lugol solution. Cell abundance were determined under the inverted microscope (Utermohl, 1958) on $100 \mathrm{ml}$ settled volumes.

\subsection{Bacteria, nanoflagellates and microzooplankton biomass and production}

Heterotrophic bacteria and heterotrophic nanoflagellates (HNAN) were counted by epifluorescence microscopy as described in Christaki et al. (1999). During the March 1997 cruise, heterotrophic nanoflagellates (HNAN) were sampled only in the S. Aegean Sea. Bacterial abundance data were converted into biomass using a conversion factor of $20 \mathrm{fg} \mathrm{C} \mathrm{cell}^{-1}$ (Lee and Fuhrman, 1987). Biovolume-carbon conver-

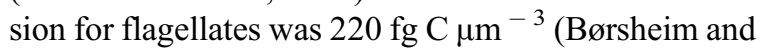
Bratbak, 1987). Bacterial production (BP) was estimated by the ${ }^{3} \mathrm{H}$-leucine method (Kirchman, 1993; for more details see Van Wambeke et al., 2000 and Christaki et al., 1999). Bacterial grazing by HNAN was measured based on ingestion of fluorescent-labelled minicells (Pace et al., 1990; Christaki et al., 1999). HNAN production was calculated as biomass $\times$ growth rate (equal to 0.17 day $^{-1}$, Kuosa and Kivi, 1989). The carbon demand of HNAN was calculated assuming a growth yield of 33\% (Hansen et al., 1997).

Ciliates were counted under a fluorescenceinverted microscope (Pitta and Giannakourou, 2000). Biovolume-carbon conversion for ciliates was $0.14 \mathrm{pg}$ $\mathrm{C} \mu \mathrm{m}^{-3}$ (Putt and Stoecker, 1989) Their production 


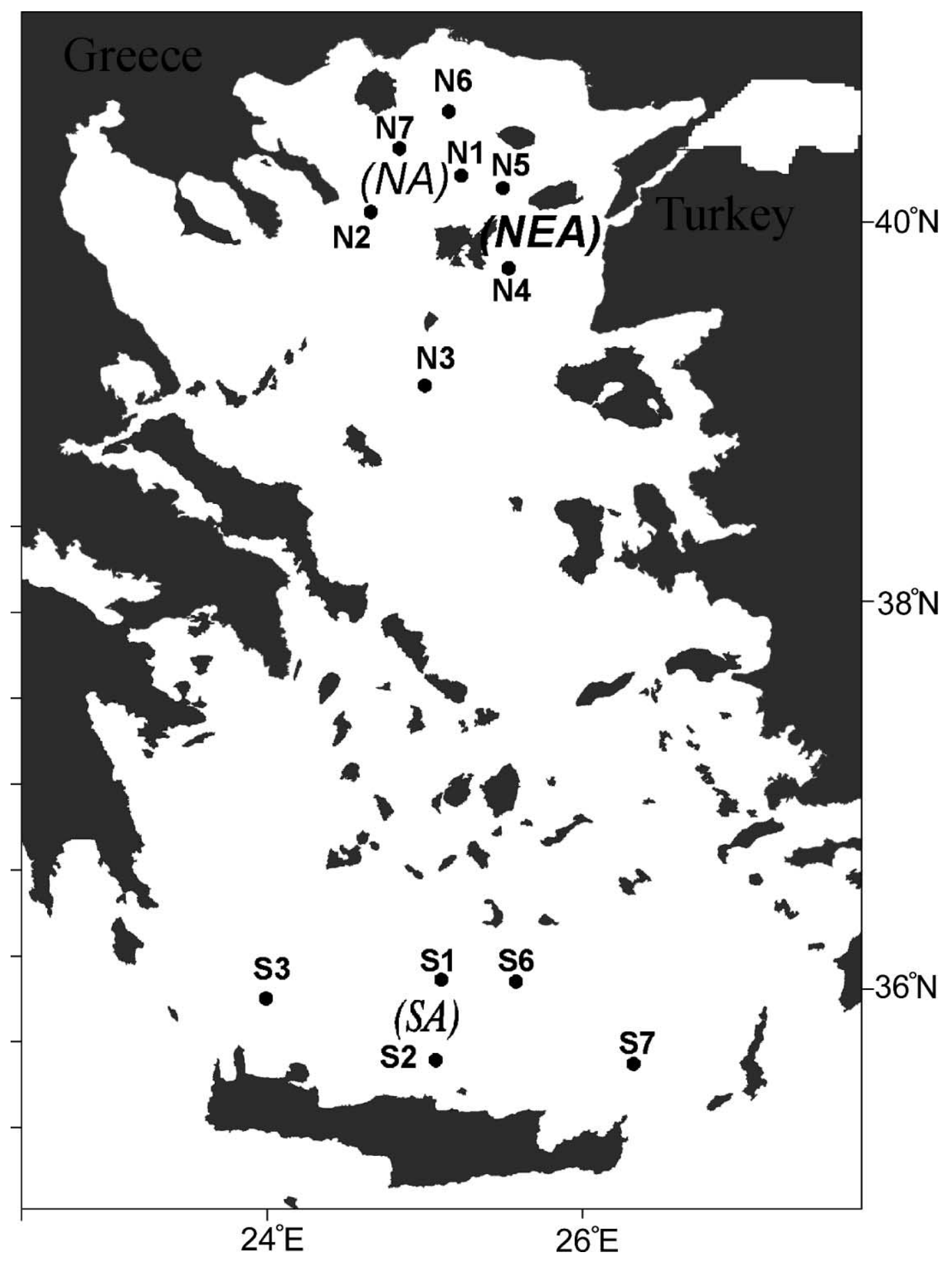

Fig. 1. Sampling stations. 
was calculated as biomass $\times$ growth rate $\left(0.55\right.$ day $\left.^{-1}\right)$ and the carbon demand was calculated assuming a growth yield of $33 \%$ (Hansen et al., 1997).

Integrated values from surface to $100 \mathrm{~m}$ for bacteria, HNAN and ciliates biomass and production rates were calculated by the trapezoid rule also.

\subsection{Mesozooplankton biomass, copepod production and grazing}

Mesozooplankton samples were collected at $0-50$ and $50-100 \mathrm{~m}$ layers by vertical haul of a WP-2 net $(200 \mu \mathrm{m})$ during daytime. Biomass was estimated from dry weight values, which were converted into carbon units assuming a $40 \%$ carbon content (Gorsky et al., 1988). Samples were collected at $0-100 \mathrm{~m}$ by the above net during daytime for the estimation of copepod production and in midday and midnight for grazing. Egg production rates of the dominant calanoid copepods were determined by incubation of fertilised females. For the final estimation of copepod production, lengths (copepods and eggs) were converted to body carbon (Hopcroft et al., 1998) and production was estimated from biomass and weight-specific egg production rates, by assuming that those rates are representative for juvenile specific growth rates (Berggreen et al., 1988). The carbon demand of the copepod community was estimated from production rates by assuming one-third gross growth efficiency (Kiorboe et al., 1985; Peterson, 1988). Copepod grazing on autotrophs was estimated from gut fluorescence measurements made according to the method described by Mackas and Bohrer (1976), as modified by Morales et al. (1990). The gut evacuation rate was calculated according to Dam and Peterson (1988).

Differences among areas and seasons, regarding biomass and production data, were tested by a oneway ANOVA (area or season) and differences were considered as significant at $p<0.05$. The Tukey test was employed for comparison among areas or seasons.

\section{Results}

\subsection{Hydrology}

Fig. 2 sums up the water-column structure in the regions of the Northeast, North and South Aegean during the cruises of March and September 1997. As expected, the South Aegean (station S1) exhibited very small salinity differences from the surface down to $300 \mathrm{~m}$. The summer stratification was attributed entirely to the shallow seasonal thermocline. The surface mixed layer is about $30 \mathrm{~m}$ thick in September, characterised by high temperature and salinity due to increased evaporation, while it extended down to 130 $\mathrm{m}$ in March. Thus, we expect that there was no significant upwelling of nutrient-rich TMW waters into the euphotic zone in March. In contrast to the South Aegean, the Northeast Aegean (station N4) is highly stratified, characterised by the presence of a 20-m-thick surface layer of modified BSW. The depths below $100 \mathrm{~m}$ are occupied by LIW, while a mixture of LIW and BSW occupied the layer between 20 and $100 \mathrm{~m}$. Finally, the North Aegean station (station N2) was characterised by the dispersion of the BSW signal downwards through vertical diffusion, and thus the dilution of the LIW layer to lower salinities down to a depth of $200 \mathrm{~m}$ in the winter and $100 \mathrm{~m}$ in the summer, a period of higher stratification.

Thus, in terms of the structure of the water column, three distinct areas have been identified in the Aegean Sea during the study period. The upper 300-m part of the water column has a two-layer nature in the Northeast Aegean (NEA: stations N4 and N5), with a layer of water from the Black Sea overlying water of Levantine origin. The South Aegean (SA: stations S1, S2, S3, S6, S7) was almost homogeneously occupied by the latter water mass. The North Aegean (NA: stations N1, N2, N3, N6, and N7) had a transitional character between the two cases, as the twolayer nature of the Northeast Aegean was eroded due to vertical diffusion processes.

\subsection{Nutrients}

The nutrient (nitrates and phosphates) concentrations in the surface layer were similar among NEA, NA and SA (Fig. 3 for nitrates). In the layer above 200 $\mathrm{m}$, nitrates varied between 0.05 and $1.6 \mu \mathrm{M}$ in NEA and NA, and 0.05 and $2.5 \mu \mathrm{M}$ in SA. The range of phosphates was $0.02-0.08$ and $0.02-0.06 \mu \mathrm{M}$ for the NEA-NA and SA, respectively. The seasonal variability was low in the whole Aegean Sea. The small increase of nutrients in the NEA and NA during March is related to winter mixing. In SA, the core of the 

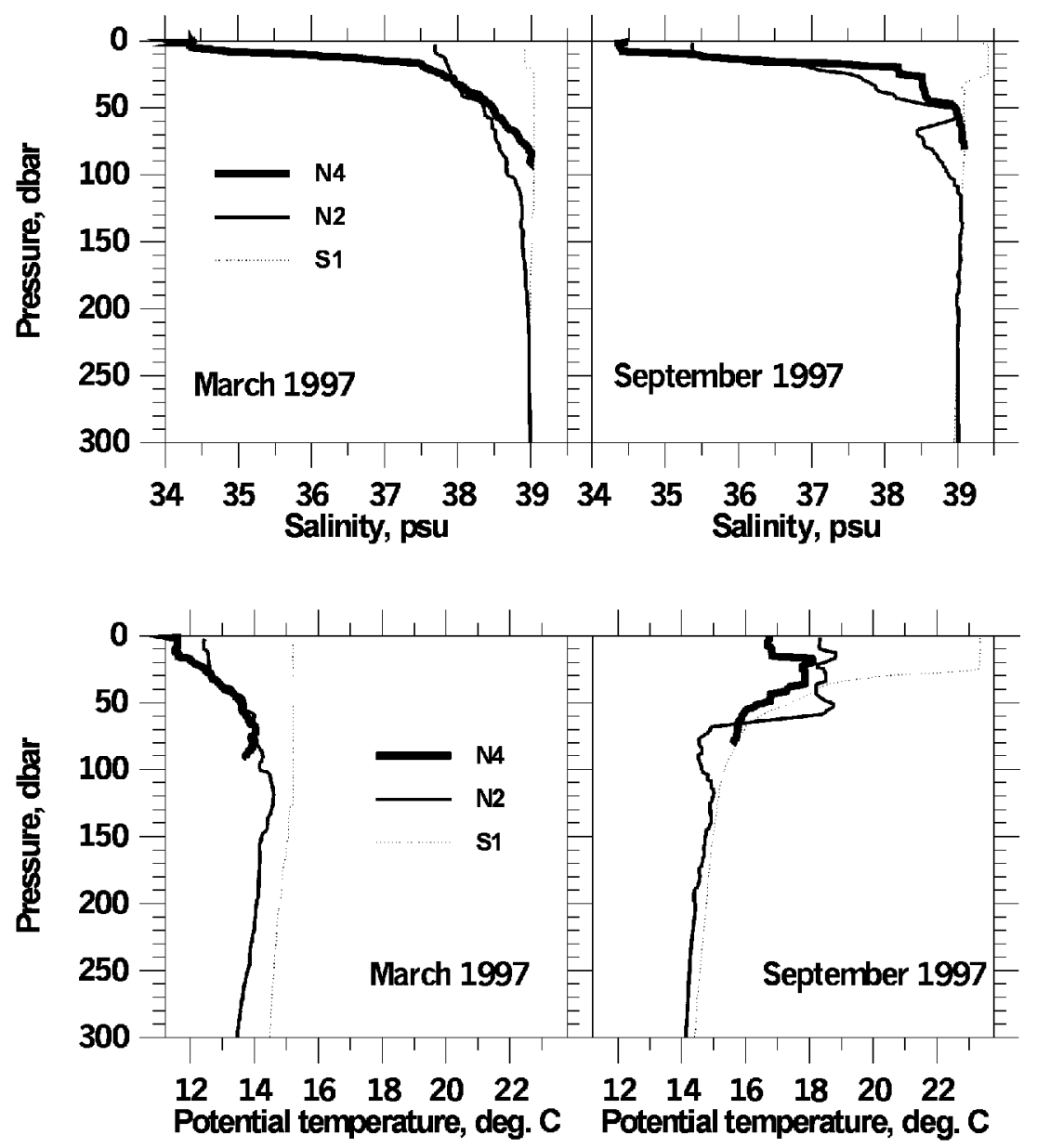

Fig. 2. Salinity (upper panel) and potential temperature (lower panel) profiles down to $100 \mathrm{~m}$, for stations characteristic of the Northeast (N4), North (N2) and South Aegean (S1) for March 1997 (left) and September 1997 (right) are presented.

"nutrient rich-oxygen poor" Transitional Mediterranean Water (TMW) lied between 200 and $300 \mathrm{~m}$ and the layer above $150 \mathrm{~m}$ was found poor in nutrients during March 1997, since the vertical mixing did not reach the nutrient-rich intermediate layer $(200-300 \mathrm{~m})$ and could not contribute to the productivity, supplying nutrients in the surface layer. The nutrient-poor surface layer was found shallower in September $(100 \mathrm{~m})$.

\subsection{Distribution of plankton biomass}

Generally, the planktonic biomass was found higher in NEA when compared to NA and SA in both seasons (Table 1), but differences were statistically significant only in March $(p=0.011)$. Although val- ues were higher in March than in September in all studied areas, differences among seasons were not significant.

\subsubsection{Autotrophs}

During March 1997 the integrated to 100-m autotrophic biomass was $2568 \mathrm{mg} \mathrm{C} \mathrm{m}^{-2}$ in NEA, 1621 $\mathrm{mg} \mathrm{C} \mathrm{m}{ }^{-2}$ in NA and $1488 \mathrm{mg} \mathrm{C} \mathrm{m}^{-2}$ in SA, but differences among areas were not significant. Smallsize cells $(<3 \mu \mathrm{m})$ dominated the autotroph population $(80 \%$ of biomass in NEA, $81 \%$ in NA and $57 \%$ in SA, Table 1). In NEA and NA, the majority of nanophytoplankton cells were $<10 \mu \mathrm{m}$ (in terms of abundance), whereas in SA most of them were larger than $10 \mu \mathrm{m}$. Furthermore, in the latter area Coccoli- 


\section{March 1997}

\section{North Aegean}

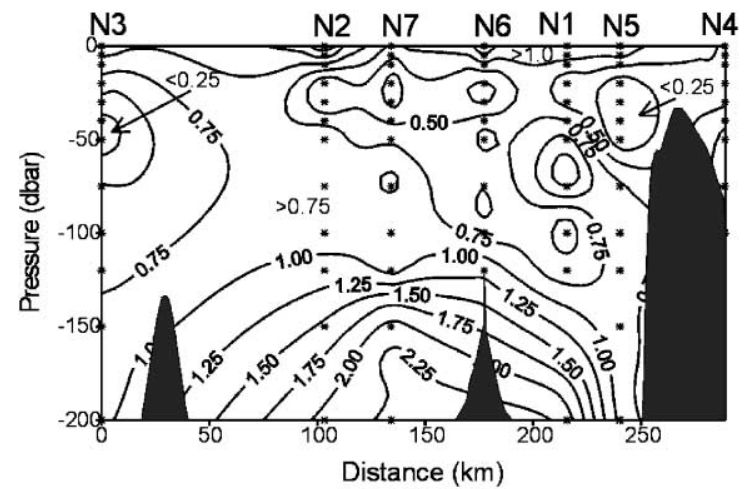

\section{September 1997}

\section{North Aegean}

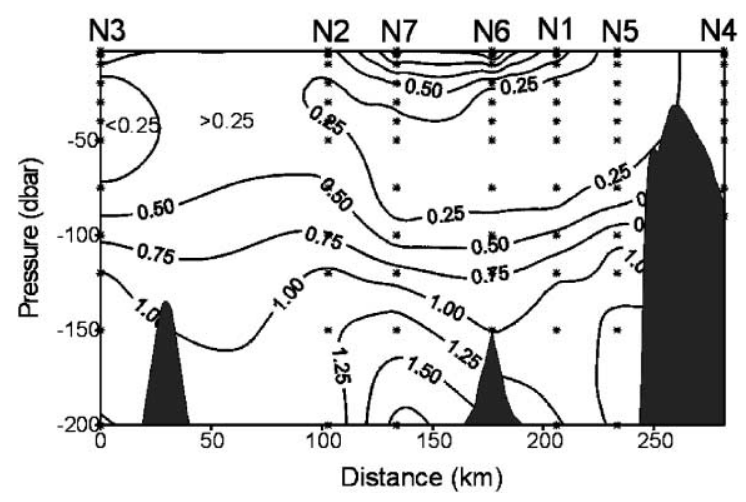

\section{South Aegean}

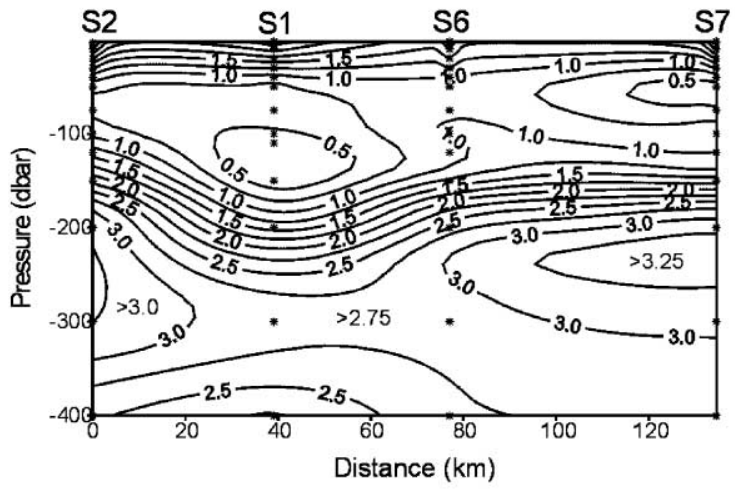

\section{South Aegean}

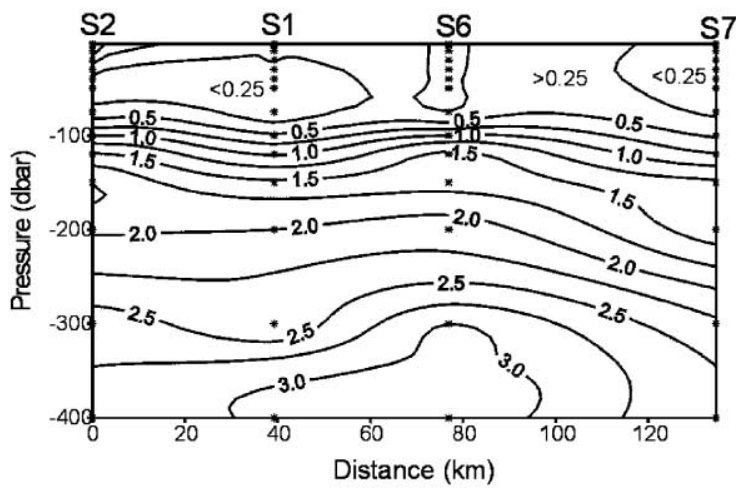

Fig. 3. Nitrate $(\mu \mathrm{M})$ distribution in the sampling areas in March and September 1997.

thophorids and Diatoms constituted the $46 \%$ and $40 \%$ (in terms of abundance), respectively, of the large size nanophytoplankton and microphytoplankton, whereas the contribution of Coccolithophorids was higher in NA (65\%) and in NEA (53\%) than in SA. It is important to stress that differences among areas regarding biomass were more important in the upper 0-50 m layer (Fig. 4) and the size distribution of autotrophic biomass was more or less similar between the upper $(0-50 \mathrm{~m})$ and the lower $(50-$ $100 \mathrm{~m}$ ) layers.

In September 1997, the biomass in the $0-100 \mathrm{~m}$ column was found higher in NEA $\left(1607 \mathrm{mg} \mathrm{C} \mathrm{m}^{-2}\right)$ than in NA $\left(1072 \mathrm{mg} \mathrm{C} \mathrm{m}^{-2}\right)$ and in SA $\left(645 \mathrm{mg} \mathrm{C}^{-}\right.$ $\left.\mathrm{m}^{-2}\right)$, but the difference was significant only between
NEA and SA $(p=0.002)$. During this period a clear difference between the upper $(0-50 \mathrm{~m})$ and lower $(50-100 \mathrm{~m})$ layers was detected only in SA, with most of the biomass found in the lower layer (Fig. 4). The contribution of the smaller cells was very important in all areas (72-82\%) (Table 1), whereas most of the larger cells (in terms of abundance) were $>10 \mu \mathrm{m}$ in all areas. The size distribution of biomass did not vary between layers in NEA and NA, whereas in SA the contribution of the larger cells was found more important in the lower layer (Fig. 4).

The autotroph biomass in the $0-100 \mathrm{~m}$ column was lower in September than in March in all areas, but the seasonal difference was significant only for NA and SA ( $p=0.03$ and $p=0.0003$, respectively). 
Table 1

Biomass (mg C m${ }^{-2}$ integrated to $100 \mathrm{~m}$ ) of autotrophs, bacteria (BACT), heterotrophic nanoflagellates (HNAN), ciliates (CIL), and mesozooplankton (MESO)

\begin{tabular}{|c|c|c|c|c|c|c|}
\hline & \multicolumn{6}{|l|}{ Area } \\
\hline & \multicolumn{2}{|l|}{ NEA } & \multicolumn{2}{|l|}{ NA } & \multicolumn{2}{|l|}{ SA } \\
\hline & Biomass & Abundance & Biomass & Abundance & Biomass & Abundance \\
\hline \multicolumn{7}{|l|}{ March } \\
\hline \multicolumn{7}{|l|}{ Autotrophs } \\
\hline $0.2-3.0 \mu \mathrm{m}$ & $2052 \pm 64(80 \%)$ & & $1320 \pm 384(81 \%)$ & & $856 \pm 311(57 \%)$ & \\
\hline$>3.0 \mu \mathrm{m}$ & $516 \pm 142(20 \%)$ & & $301 \pm 90(19 \%)$ & & $632 \pm 61(43 \%)$ & \\
\hline Total autotrophs & $2568 \pm 78$ & & $1621 \pm 426$ & & $1488 \pm 364$ & \\
\hline \multicolumn{7}{|l|}{ Heterotrophs } \\
\hline $\mathrm{BACT}$ & $1403 \pm 142$ & $8.33 \pm 3.93$ & $1406 \pm 327$ & $7.52 \pm 3.38$ & $1423 \pm 43(75 \%)$ & $8.21 \pm 1.88$ \\
\hline HNAN & & & & & $192 \pm 54(10 \%)$ & $0.34 \pm 0.14$ \\
\hline CIL & $31 \pm 11$ & $327 \pm 82$ & $17 \pm 8$ & $163 \pm 101$ & $84 \pm 20(4 \%)$ & $417 \pm 111$ \\
\hline MESO & $987 \pm 696$ & $2761 \pm 2120$ & $424 \pm 165$ & $1056 \pm 789$ & $187 \pm 43(10 \%)$ & $390 \pm 88$ \\
\hline Total heterotrophs & $2421 \pm 564$ & & $1847 \pm 364$ & & $1886 \pm 94$ & \\
\hline Total plankton & $4989 \pm 643$ & & $3468 \pm 377$ & & $3374 \pm 423$ & \\
\hline $\mathrm{H} / \mathrm{A}$ & 0.9 & & 1.1 & & 1.3 & \\
\hline $\mathrm{mH} / \mathrm{A}$ & 0.6 & & 0.9 & & 1.1 & \\
\hline \multicolumn{7}{|l|}{ September } \\
\hline \multicolumn{7}{|l|}{ Autotrophs } \\
\hline $0.2-3.0 \mu \mathrm{m}$ & $1326 \pm 539(82 \%)$ & & $817 \pm 196(76 \%)$ & & $465 \pm 64(72 \%)$ & \\
\hline$>3.0 \mu \mathrm{m}$ & $281 \pm 76(18 \%)$ & & $255 \pm 33(24 \%)$ & & $180 \pm 33(28 \%)$ & \\
\hline Total autotrophs & $1607 \pm 616$ & & $1072 \pm 227$ & & $645 \pm 81$ & \\
\hline \multicolumn{7}{|l|}{ Heterotrophs } \\
\hline Bact & $1251 \pm 107(66 \%)$ & $6.67 \pm 1.82$ & $1471 \pm 273(69 \%)$ & $7.14 \pm 3.01$ & $1505 \pm 432(59 \%)$ & $6.88 \pm 2.57$ \\
\hline HNAN & $301 \pm 31(16 \%)$ & $1.43 \pm 0.92$ & $418 \pm 90(20 \%)$ & $0.96 \pm 0.37$ & $812 \pm 376(32 \%)$ & $1.14 \pm 0.4$ \\
\hline CIL & $18 \pm 1(1 \%)$ & $184 \pm 1$ & $31 \pm 8(1 \%)$ & $155 \pm 54$ & $65 \pm 24(3 \%)$ & $152 \pm 21$ \\
\hline MESO & $338 \pm 120(18 \%)$ & $2099 \pm 654$ & $207 \pm 38(10 \%)$ & $1594 \pm 411$ & $156 \pm 44(6 \%)$ & $706 \pm 272$ \\
\hline Total heterotrophs & $1908 \pm 195$ & & $2127 \pm 225$ & & $2538 \pm 607$ & \\
\hline Total plankton & $3515 \pm 811$ & & $3199 \pm 219$ & & $3183 \pm 577$ & \\
\hline $\mathrm{H} / \mathrm{A}$ & 1.2 & & 2 & & 3.9 & \\
\hline $\mathrm{mH} / \mathrm{A}$ & 1 & & 1.8 & & 3.7 & \\
\hline
\end{tabular}

$\mathrm{H} / \mathrm{A}=$ ratio of heterotrophs over autotrophs, $\mathrm{mH}=$ microheterotrophs (bacteria + heterotrophic nanoflagellates + ciliates).

(\%): Percentage of the biomass of each group compared to total heterotrophs or total autotrophs. In March there was no sampling for nanoflagellates in the North Aegean Sea.

Abundance (mean integrated to $100 \mathrm{~m}$ ) of bacteria (cells $\times 10^{8} 1^{-1}$ ), heterotrophic nanoflagellates (cells $\times 10^{6} 1^{-1}$ ), ciliates $\left(\right.$ cells $1^{-1}$ ), mesozooplankton (ind $\mathrm{m}^{-3}$ ).

$\mathrm{NEA}=$ Northeast Aegean, NA= North Aegean, $\mathrm{SA}=$ South Aegean .

\subsubsection{Heterotrophs}

In March, the biomass of heterotrophs was higher in NEA (2421 $\left.\mathrm{mg} \mathrm{C} \mathrm{m}^{-2}\right)$ than in NA $(1847 \mathrm{mg} \mathrm{C}$ $\mathrm{m}^{-2}$ ) and SA (1886 $\mathrm{mg} \mathrm{C} \mathrm{m}^{-2}$, Table 1). Bacteria constituted the largest fraction of the heterotrophic carbon and their biomass did not vary significantly among areas. Although ciliate biomass was very low in all areas, it was significantly higher in SA than in NA and NEA $(p=0.0008)$. In contrast, mesozooplankton biomass decreased significantly from NEA to NA and even more to SA ( $p=0.007)$. In terms of abundance copepods constituted the bulk of mesozooplankton $(93 \%$ in NEA, $81 \%$ in NA and $74 \%$ in SA) and the presence of appendicularians was quite important in SA $(10 \%)$ and in NA $(6 \%)$. It is worth mentioning that if we consider the integrated values in the $0-50$ and $50-100 \mathrm{~m}$ layers separately, total heterotrophic biomass was higher in the upper than the lower layer (Fig. 5). Within the upper layer, there was gradual decrease of heterotrophic biomass from 


\section{MARCH 1997}
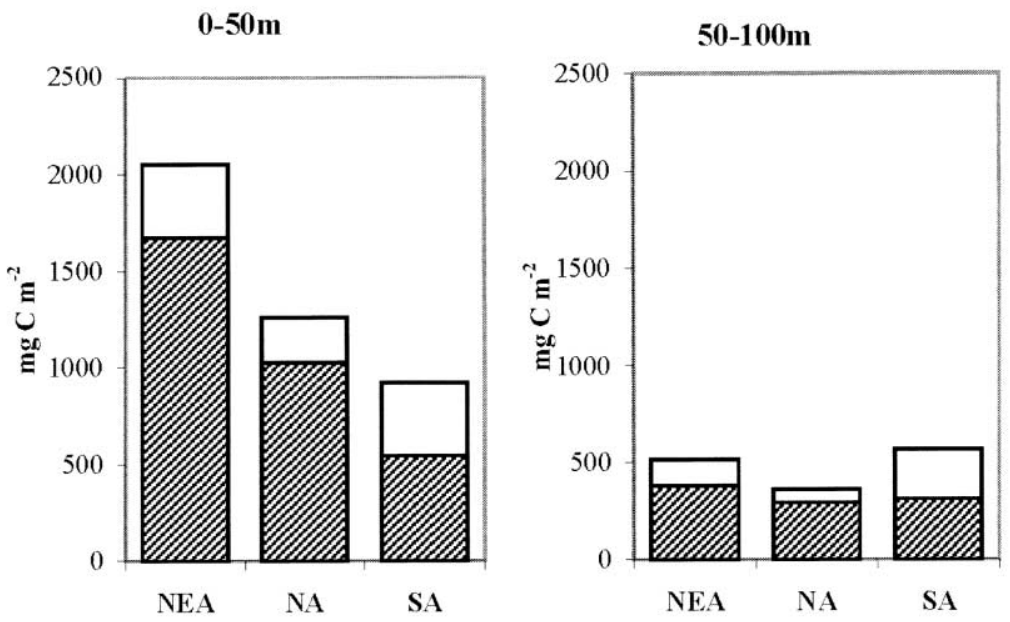

\section{SEPTEMBER 1997}
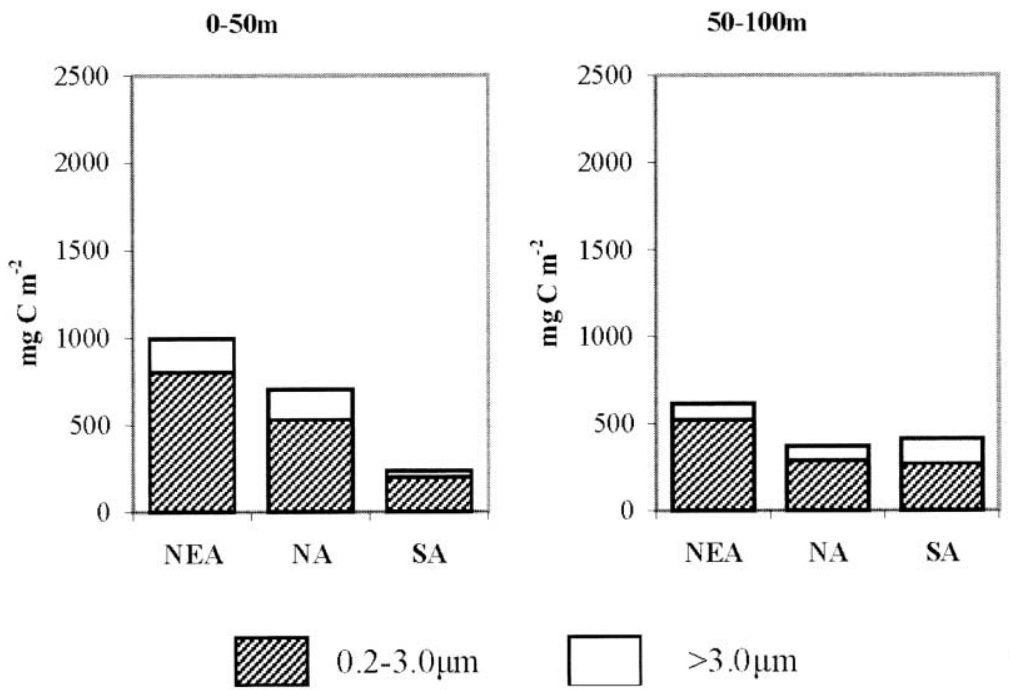

Fig. 4. Biomass distribution of autotrophs in the 0-50 and 50-100 m layers during March and September 1997.

NEA to NA and SA, due to mesozooplankton biomass decrease. In the lower layer heterotrophic biomass was slightly higher in SA than in NA and NEA and interestingly mesozooplankton biomass decreased from NEA to SA accompanied by a parallel increase of bacteria.
In September 1997, heterotrophic biomass was found increasing from NEA $\left(1907 \mathrm{mg} \mathrm{C} \mathrm{m}^{-2}\right)$ to $\mathrm{NA}\left(2126 \mathrm{mg} \mathrm{C} \mathrm{m}^{-2}\right)$ and SA $\left(2537 \mathrm{mg} \mathrm{C} \mathrm{m}^{-2}\right)$ due to the contribution of bacteria, heterotrophic nanoflagellates (HNAN) and ciliates (Table 1). Bacterial contribution was high in all areas, representing 59- 


\section{MARCH 1997}
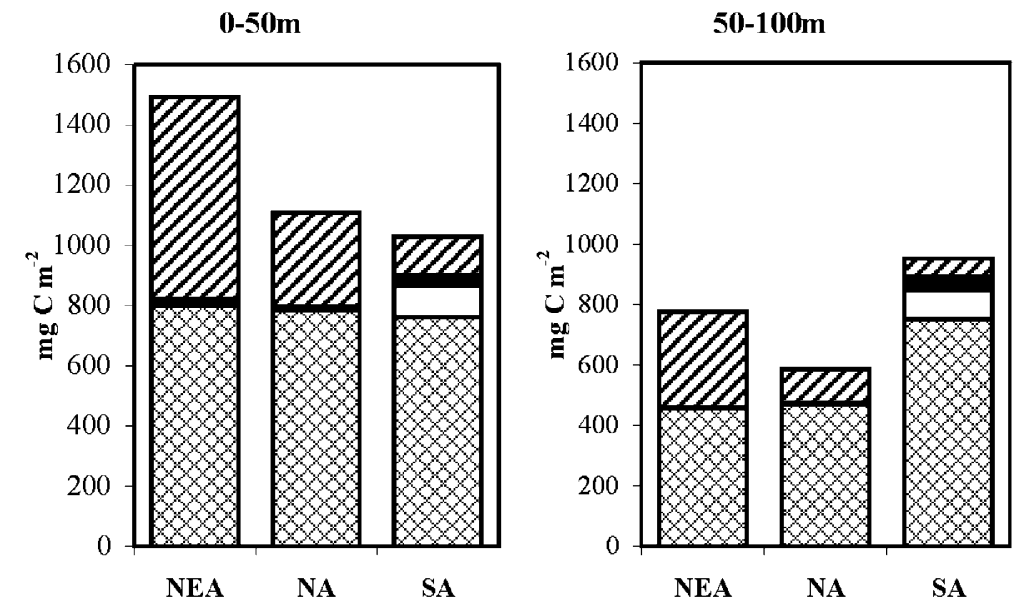

\section{SEPTEMBER 1997}
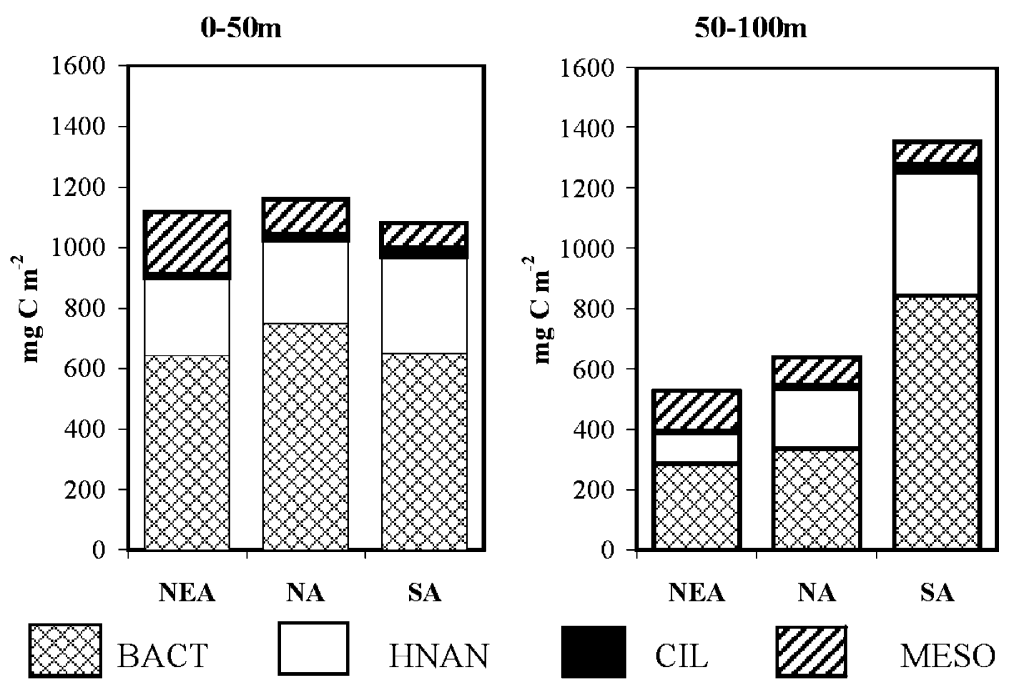

Fig. 5. Biomass distribution of heterotrophs in the 0-50 and 50-100 m layers during March and September 1997 (BACT=bacteria, $\mathrm{HNAN}=$ heterotrophic nanoflagellates, $\mathrm{CIL}=$ ciliates, $\mathrm{MESO}=$ mesozooplankton $)$.

$69 \%$ of the total heterotrophs. The contribution of HNAN was lower than that of bacteria and even more than that of ciliates $(1-3 \%$ in all areas). Interestingly, ciliate biomass was significantly higher in SA than in NEA and NA $(p=0.01)$. The biomass of mesozooplankton decreased significantly from NEA towards SA $(p=0.02)$, as well as its contribution to total heterotrophic biomass. On considering the distribution of heterotrophic biomass in the $0-50$ and $50-100 \mathrm{~m}$ layers, the upper layers showed no differences, but the lower layer exhibited an increase from NEA and NA to SA due to bacteria and HNAN contribution (Fig. 5). During this period, cladocerans were abundant (especially Penilia avirostris) in NEA (12\% of total mesozooplankton abundance) and NA (19\%); in the same areas the presence of appendicularians was important $(20 \%$ and $7 \%$, respectively, in terms of abundance).

During September, the heterotrophic biomass was lower than March in NEA, but higher in SA. Bacterial 
MARCH 1997

NEA

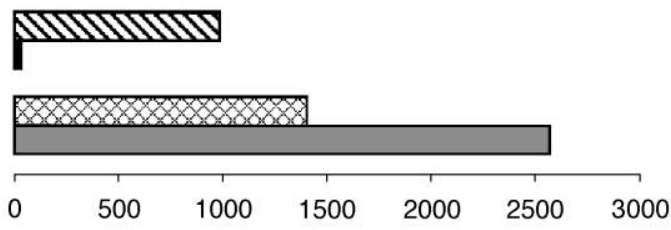

NA

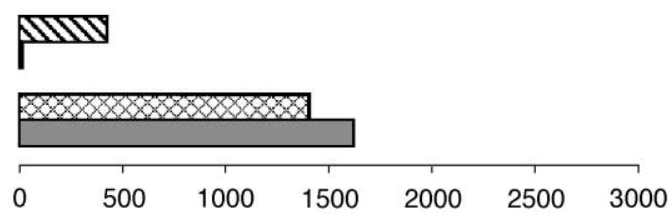

SA

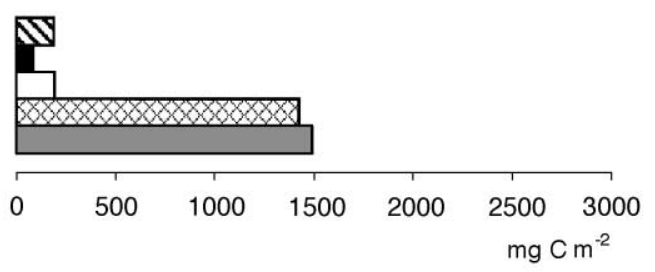

SEPTEMBER 1997

NEA

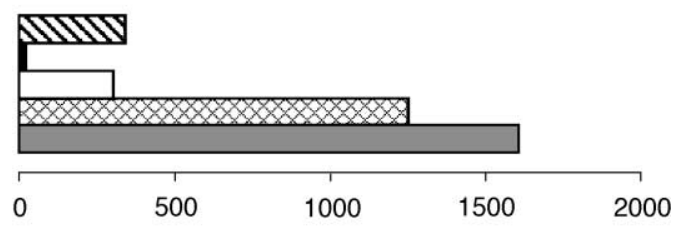

NA

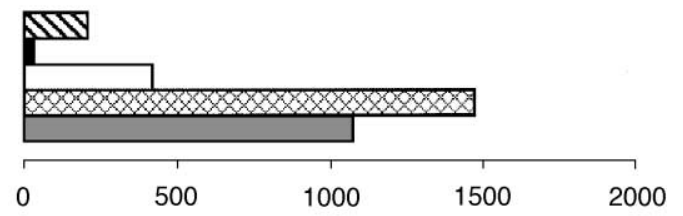

SA

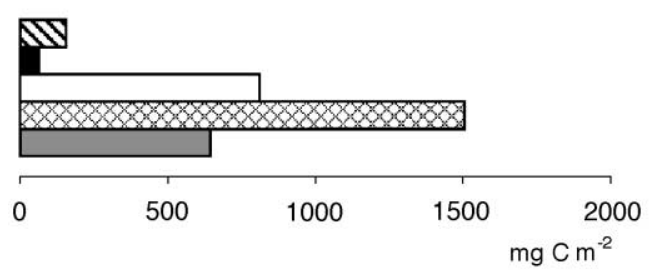

HNAN

Fig. 6. Carbon partitioning among auto- and heterotrophs in March and September 1997. Auto: autotrophic biomass; BACT: heterotrophic bacteria; HNAN: heterotrophic nanoflagellates; CIL: ciliates; MESO: mesozooplankton.

biomass was not different to that found in March in the whole region, whereas mesozooplankton was lower in September than in March, but seasonal difference was significant only in NA $(p=0.008)$.

\subsubsection{Carbon partitioning}

The partitioning of carbon among the different plankton compartments was not a broad-based pyramid where autotrophs' biomass overwhelms that of heterotrophs, in all areas and in both seasons (Table 1, Fig. 6). During March the ratio of total heterotrophs/ autotrophs was 0.9 in NEA, 1.1 in NA and 1.3 in SA, due to the importance of microheterotrophs (Bacter$\mathrm{ia}+\mathrm{HNAN}+$ Ciliates), especially in SA. The contribution of autotrophs in the plankton biomass was lower in September and the heterotrophs/autotrophs ratio was 1.2 in NEA, 2 in NA and 3.9 in SA. These values imply a gradual decreasing contribution of autotrophs and a parallel increasing contribution of heterotrophs from NEA to SA, which was due to microheterotrophs.

\subsection{Planktonic production and carbon flow}

In March 1997, primary production was found decreasing significantly $(p=0.0018)$ from NEA (2339 $\mathrm{mg} \mathrm{C} \mathrm{m}^{-2}$ day $\left.^{-1}\right)$ to NA (1406 $\mathrm{mg} \mathrm{C} \mathrm{m}^{-2}$ day $^{-1}$ ) and SA (574 $\mathrm{mg} \mathrm{C} \mathrm{m}^{-2}$ day $^{-1}$ ) (Table 2). Almost $77 \%$ and $73 \%$ of primary production was due to cells $<3 \mu \mathrm{m}$ in NEA and NA, respectively, whereas in SA this contribution was lower $(60 \%)$. In NEA, primary production was higher in the upper $(0-50 \mathrm{~m})$ layer than in the lower layer $(50-100 \mathrm{~m})$ and this difference was small in NA and even smaller in SA. 
Table 2

Primary, bacterial and copepod production in the study areas

\begin{tabular}{|c|c|c|c|c|c|}
\hline & $\begin{array}{l}\text { PP } \\
\left(\mathrm{mg} \mathrm{C} \mathrm{m}^{-2} \text { day }^{-1}\right)\end{array}$ & $\begin{array}{l}\mathrm{BP} \\
\left(\mathrm{mg} \mathrm{C} \mathrm{m}^{-2} \text { day }^{-1}\right)\end{array}$ & $\begin{array}{l}\text { Copepod production } \\
\left(\mathrm{mg} \mathrm{C} \mathrm{m}^{-2} \text { day }^{-1}\right)\end{array}$ & $\begin{array}{l}\mathrm{PP}<3 \mu \mathrm{m} \\
(\% \text { of total PP) }\end{array}$ & $\mathrm{BP} / \mathrm{PP}$ \\
\hline \multicolumn{6}{|c|}{ March } \\
\hline NEA & $2339 \pm 905$ & $110 \pm 77$ & $41 \pm 31$ & 76.66 & 0.05 \\
\hline NA & $1406 \pm 362$ & $48 \pm 31$ & $5 \pm 2$ & 72.54 & 0.03 \\
\hline SA & $574 \pm 176$ & $75 \pm 9$ & $5 \pm 3$ & 59.76 & 0.13 \\
\hline \multicolumn{6}{|c|}{ September } \\
\hline NEA & $221 \pm 13$ & 71 & $58 \pm 45$ & 73.73 & 0.32 \\
\hline NA & $253 \pm 70$ & $60 \pm 11$ & $15 \pm 2$ & 67.19 & 0.24 \\
\hline SA & $218 \pm 63$ & $58 \pm 13$ & $6 \pm 4$ & 58.26 & 0.27 \\
\hline
\end{tabular}

Bacterial production was higher in NEA than in the other areas but differences were not significant. This production was very low as compared to $\mathrm{PP}$ as it is clear from the ratio BP/PP: $0.03-0.13$. Copepod production was found significantly higher in the NEA than in NA and SA.

No difference was detected among areas regarding primary production in September and the contribu- tion of the smaller cells was found decreasing from NEA to SA. In NEA and NA primary production was slightly higher in the upper than in the lower layer, but there was no difference among layers in SA. Low values of bacterial production were detected during this period in all areas $(58-71 \mathrm{mg}$ $\mathrm{C} \mathrm{m}^{-2}$ day $\left.{ }^{-1}\right)$. The BP/PP ratio values were higher during this period $(0.24-0.32)$ due to the important

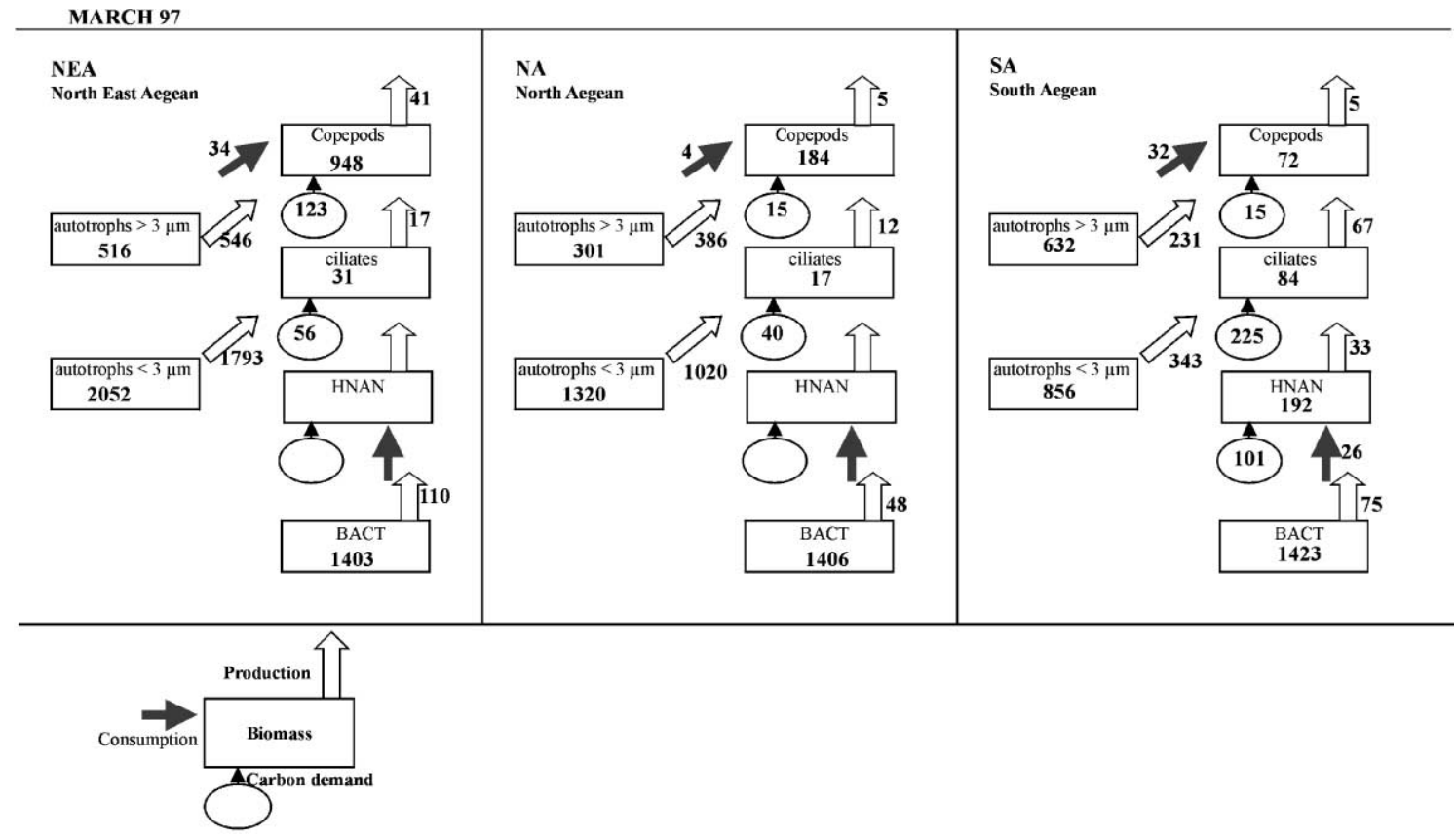

Fig. 7. Carbon budgets in March 1997. Numbers inside boxes show biomasses ( $\mathrm{mg} \mathrm{C} \mathrm{m}^{-2}$ ); numbers inside ellipses show carbon demands (mg $\mathrm{C} \mathrm{m}^{-2}$ day ${ }^{-1}$ ); numbers below the white arrows show productions $\left(\mathrm{mg} \mathrm{C} \mathrm{m}^{-2}\right.$ day ${ }^{-1}$ ) and above black arrows show consumption (mg $\mathrm{C}$ $\mathrm{m}^{-2}$ day $^{-1}$ ). 

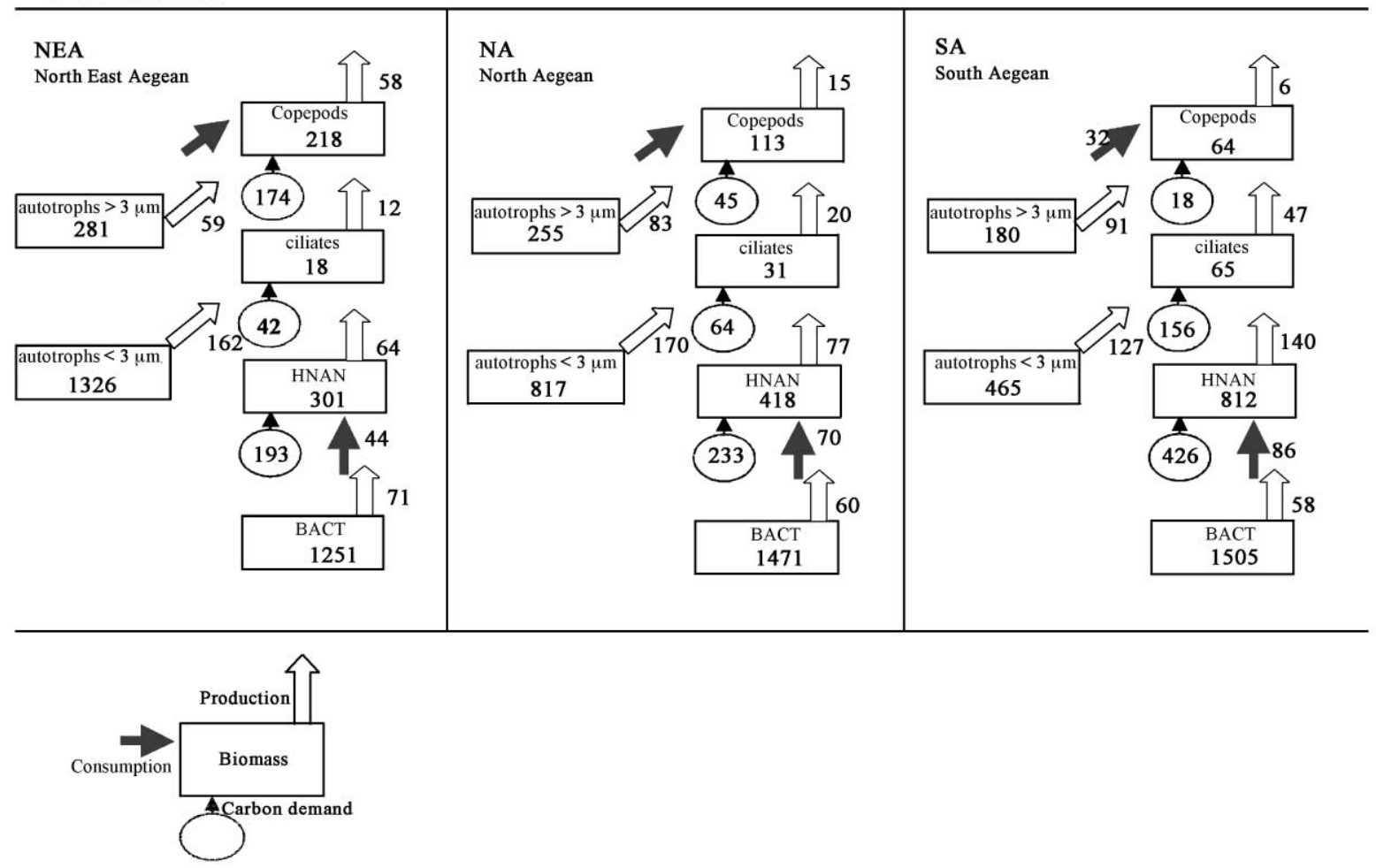

Fig. 8. Carbon budgets in September 1997.

decrease of primary production. A decrease of copepod production was found from NEA (58 $\mathrm{mg} \mathrm{C}$ $\mathrm{m}^{-2}$ day $\left.^{-1}\right)$ to NA $\left(15 \mathrm{mg} \mathrm{C} \mathrm{m}^{-2}\right.$ day $\left.^{-1}\right)$ and SA (6 $\mathrm{mg} \mathrm{C} \mathrm{m}^{-2}$ day $^{-1}$ ).

Primary, bacterial and copepod productions were lower in September than in March, but seasonal difference was significant only for primary production.

Carbon stocks and flux within autotrophs (cells $<3$ $\mu \mathrm{m}$ and cells $>3 \mu \mathrm{m}$ ), bacteria, heterotrophic nanoflagellates, ciliates and copepods were established for the investigated areas and seasons. Values presented in the figures are average values for all stations of each sampling area. (Figs. 7 and 8). Standing stocks (and rates) are presented as $\mathrm{mg} \mathrm{C} \mathrm{m}^{-2}\left(\right.$ day $^{-1}$ ).

During March 1997, the carbon budget suggests a balance between prey and predators in all areas, except in SA, where bacterial production could not satisfy the carbon demand of HNAN. However, this demand could be met also by the primary production of cells $<3 \mu \mathrm{m}$. Copepods have been found to consume a greater proportion of the larger cell production in SA (14\%) than in NEA (6.2\%) and NA $(1 \%)$.

Similarly, in September there is a balanced carbon budget in all areas, with two exceptions: in NEA the carbon demand of copepods could be roughly balanced by the production of the larger autotrophs together with that of ciliates. In SA, the bacterial production together with the smaller cell primary production is not enough for the carbon demand of HNAN. In this region, copepods consumed $35 \%$ of the larger cell production. Overall there was a lower availability of food to all trophic levels in September than in March.

In both seasons there was a greater availability of prey to the microheterotroph carbon demand in NEA than in SA; in contrast, there was a lower availability of prey to copepod carbon demand in NEA than in SA. It is important to stress that the measured HNAN bacterivory matched more or less the bacte- 
rial production in all studied areas (Christaki et al., 1999).

\section{Discussion}

\subsection{Trophic state of the study area and carbon partitioning within the food web}

Our findings suggest that the Aegean Sea is an area of low nutrients, plankton biomass and production, as the rest of the eastern Mediterranean Sea (Berman et al., 1984; Krom et al., 1993; Robarts et al., 1996; Mazzocchi et al., 1997). Besides the confirmation of the oligotrophic character of the area, in terms of both biomass and production, they also revealed another interesting feature: the existence of a North-South gradient within this oligotrophic region.

The concentration of nutrients in the surface layer of NEA and NA is of the same low level as in SA. According to Polat and Tugrul (1996), the annual mean concentration of dissolved inorganic nitrogen (DIN) in the surface water outflowing from Bosphorus is $1.81 \mu \mathrm{M}$ and that of dissolved inorganic phosphorus (DIP) is $0.11 \mu \mathrm{M}$. However, in the surface water outflowing from Dardanelles, the annual mean concentrations of DIN and DIP are low (0.48 and $0.09 \mu \mathrm{M}$, respectively) and these values are very close to those detected during the present study. They also found that the Black Sea surface outflow reaches the Aegean basin with large dissolved organic nitrogen (DON) and dissolved organic carbon (DOC) values, due to their low decay rates, but with a net decrease in the mean nitrate value due to consumption in the Marmara basin. The significantly higher total organic carbon (TOC) values, observed in the low salinity upper layer of NEA relatively to those of SA (Sempere et al., 2002), confirm the above findings.

Although nutrients showed similar values all over the studied area, there is a gradual differentiation of the planktonic community from the Dardanelles strait (Northeast Aegean) to the Cretan Arc straits (South Aegean). Autotrophic biomass decreased from NEA to NA and SA in both seasons as well as primary production during March, suggesting an increasing trend of oligotrophy from the area influenced by the Black Sea Water (NEA) towards the deep basin of the
South Aegean Sea. This inverse correlation between nutrients and autotrophs (low nutrient concentrations-high biomass), regarding the North Aegean, might be characterised as "an anomalous interrelationship" that has been recorded previously in the Gulf of California (Hernandez-Becerril, 1987). However, nitrate and ammonium uptake experiments performed in the framework of the project have shown elevated new production values during March 1997: $\mathrm{NO}_{3}$ uptake rates about 10 times higher at NEA than NA or SA (Psarra, unpublished data). These features suggest an input of new nutrients in the euphotic zone from the Black Sea, which enrich the area, but are very rapidly assimilated and thus significantly reduced.

Similar spatial pattern (decrease from NEA to NA and SA) was observed for mesozooplankton biomass and copepod production, suggesting the existence of the oligotrophy gradient within the Aegean Sea even in the higher trophic levels. Since this differentiation was detected mainly in the $0-50 \mathrm{~m}$ layer, it can be attributed to the influence of the BSW, which occupies the upper $20 \mathrm{~m}$ of the water column.

Bacterial biomass was more or less horizontally homogeneous in March 1997, but in September it showed, together with that of HNAN, an increase from NEA to NA and SA. Ciliates exhibited a similar pattern from NEA to SA in both seasons. Overall the ratios Heterotrophs/Autotrophs and Microheterotrophs/Autotrophs were high and increasing from NEA to SA. They were also higher in September compared to March. The H/A values found in the SA were close to those found in the Sargasso Sea (and with a similar seasonal variability), where the microbial loop has been found dominant (Roman et al., 1995). These findings imply that microheterotrophs play a very important role in the whole Aegean Sea and this role seems to be more significant in SA than in NA and NEA, whereas on a temporal scale, it is more important during the stratification period (September) than during the mixing period (March).

In the Aegean Sea, most of the autotrophic carbon biomass (almost $80 \%$ ) and primary production $(75 \%)$ was due to small-sized cells $(<3 \mu \mathrm{m})$, except in the SA during March. It appears as though this smaller cell autotrophic biomass can support an equal (during March) or greater (during September) heterotrophic 
biomass, which becomes more important from NEA to SA. It is assumed that more photosynthetic DOC would flow to the microbial loop if nano- and picophytoplankton dominate the phytoplankton community (Huang et al., 1999).

\subsection{Trophic pathways and carbon flow}

The bacterial to primary production (BP/PP) ratio was found to be lower in NEA and NA than in SA in March (0.05 and 0.03 versus 0.13), whereas in September this ratio was generally higher $(0.23-0.32)$. In the Levantine Basin in September, Robarts et al. (1996) reported BP/PP ratios of 0.55. Turley et al. (2000) found that bacterial production comprised 34\% of the integrated primary production in the eastern Mediterranean Sea and 21\% in the western Mediterranean Sea. They have hypothesised that a greater proportion of the primary production may flow to bacteria in the eastern Mediterranean Sea than in the western Mediterranean Sea and consequently a smaller amount of production is left for the higher trophic levels in the former area than in the latter. Based on the above hypothesis, we could assume that the observed lower BP/PP ratio in NEA and NA than in SA during March suggests that the same difference seems to exist in the Aegean Sea at a N-S direction; thus a higher proportion of primary production is left for the higher trophic levels in NEA than in SA.

However, it is also worth recalling that the increase of this ratio from March to September could reflect temporal variations, as more phytoplankton-derived material is available for bacteria during post-bloom situations; it also reflects the lag between peaks of primary and bacterial production, as it was described in a temporal survey in western Mediterranean (Van Wambeke et al., 2002) and the eastern basin (Van Wambeke et al., 2000). A similar seasonal variability of the BP/PP as that observed in the Aegean Sea, has been detected in the Sargasso Sea (Roman et al., 1995).

Clearly, many different mechanisms may account for the BP/PP ratio variability. Local temporal changes can be caused spatial short-scale variability as, for example, frontal structures (Fernàndez et al., 1994; Yoro et al., 1997) or allochthonous detritus or DOC advection in coastal waters (Pedros-Alio et al., 1999; Van Wambeke et al., 2002); such phenomena may contribute to measuring a greater variability of this ratio in Mediterranean (Conan et al., 1999).

The whole study area was dominated by smallsized $(<3 \mu \mathrm{m})$ primary producers, which are not grazed by copepods but are rather consumed by nanoand microheterotrophs; therefore, most of the fixed carbon flows through the microbial food web (Legendre and Rassoulzadegan, 1995). However, the contribution of the small autotrophs was found decreasing from NEA towards SA, accompanied by a parallel increase of microheterotrophs, suggesting a differentiation in the trophic pathways and the carbon flow between these areas.

The very low grazing pressure of copepods on primary production during March in NA and NEA when compared to SA, suggests that copepods could not efficiently consume microphytoplankton in the former areas. This could be due to the small size $(<10 \mu \mathrm{m})$ of most microphytoplankters found in NEA and NA, since copepods feed better on $>10$ $\mu \mathrm{m}$ particles (Fortier et al., 1994; Nielsen and Hansen, 1995). The above findings related to the very low ciliate biomass in NEA and NA, confirms the hypothesis of the strong top-down control of the ciliate population in these regions (Pitta and Giannakourou, 2000); low concentrations of ciliates may be due to copepod predation (Nielsen and Kiorboe, 1991; Bradford-Grieve et al., 1999; Levinsen et al., 1999). In contrast, in SA the observed higher biomass of ciliates could be attributed to a weaker grazing control by mesozooplankters. The differences detected in mesozooplankton and ciliate community composition within the Aegean Sea (Siokou-Frangou et al., manuscript in preparation; Pitta and Giannakourou, 2000), probably may account for the different among areas grazing pressure on ciliates, due to prey selectivity.

According to the classification of the trophic pathways given by Legendre and Rassoulzadegan (1995), a microbial food web (as a more open system than the microbial loop which also includes autotrophic picoand nanoplankton) seems to have been developed during March 1997 in NEA and NA. During the stratification period (September) the same pathways were important, but no information is available for the grazing pressure of copepods on phytoplankton in the above regions. Interestingly this pressure was found significant in SA during March and much more in 
September. Therefore, in the latter area the food web could be classified as multivorous (where herbivorous and microbial grazing modes both have significant roles).

Besides copepods, appendicularians contributed significantly in the mesozooplankton community in March (mainly in SA), as well as in September (mainly in NEA and NA). Appendicularians can feed on small particles $(<15 \mu \mathrm{m})$ (Alldredge, 1981) and present high grazing rates (Hopcroft and Roff, 1995). The cladoceran $P$. avirostris, which was found dominant among mesozooplankton in NEA and NA during September, appears to be adapted for suspension feeding on particles as small as $2 \mu \mathrm{m}$ (Turner et al., 1988). Thus, although the carbon demand and the production of appendicularians and cladocerans have not been estimated, one can hypothesise that during September in NEA and NA, a non-negligible portion of heterotrophic and autotrophic picoplankton and nanoplankton production was be harvested by mesozooplankton. This indicates that during the period of low primary production (September) more efficient pathways were developed within the food web in NEA and NA. The reduction of mass transfer through intermediate populations of microbial predators is of considerable bioenergetic significance, since these mesozooplankters can mediate the microbial biomass directly to fish (Deibel and Lee, 1992; Fortier et al., 1994). Moreover, appendicularians and cladocerans present a high population growth rate under favourable conditions (Gorsky, 1989; Egloff et al., 1997) and they could contribute to a high carbon turnover in NEA and in NA. This assumption together with the observed differences in the mesozooplankton biomass and copepod production among areas suggest that there is a better transfer of energy towards mesozooplankters in NEA than in NA and SA. Therefore, one could assume that this difference in the degree of energy transfer will be reflected in the higher trophic levels: fish (Stergiou et al., 1997) and benthos (Lykousis et al., 2002). The lower grazing pressure of copepods and greater availability of the smaller autotrophs to microheterotroph carbon demand in NEA than in SA suggest that there will be a greater export of primary production from the euphotic zone in NEA than in SA. Lykousis et al. (2002) have found higher fluxes of labile POC in the Northern part of the Aegean Sea than in the Southern.

\section{Conclusions}

The results of this study confirm our hypothesis that there is a spatial differentiation within the Aegean Sea regarding the pelagic food web structure and the carbon flow within it. This differentiation both in terms of biomass and production, was expressed along a gradient of oligotrophy from the Northeast Aegean Sea (NEA), which is influenced by the BSW, towards the South Aegean Sea (SA). The microbial food web seems to have been developed in NEA and NA, whereas a multivorous food web was found in SA. Most of the carbon is fixed by small-sized cells, but the energy transfer is variable along the oligotrophy gradient. In NEA, a large part of the fixed carbon is channelled through the microbial food web towards copepods during both seasons, while during the stratification period it seems that a portion of the microbial biomass is removed by cladocerans and appendicularians, suggesting a more efficient energy transfer. In contrast, the energy transfer towards copepods in SA is low in both seasons, while an intermediate flow seems to exist in NA.

\section{Acknowledgements}

This work is part of the MTP-II-MATER project funded by the EU under the MAST III/MTP-II contract MASTIII-CT096-0051. The authors wish to thank the Captain and crew of R/V AEGAEO for their important contribution to the fieldwork and sampling. Two anonymous reviewers are also acknowledged for their comments and helpful suggestions.

\section{References}

Alldredge, A.L., 1981. The impact of appendicularian grazing on natural food concentrations in situ. Limnol. Oceanogr. 26, $247-$ 257.

Azam, F., Fenchel, T., Field, J.G., Gray, J.S., Meyer-Reil, L.A., Thingstad, F., 1983. The ecological role of water-column microbes in the sea. Mar. Ecol. Prog. Ser. 10, 257-263.

Azov, Y., 1986. Seasonal patterns of phytoplankton productivity and abundance in nearshore oligotrophic waters of the Levant Basin (Mediterranean). J. Plankton Res. 8, 41-53.

Berggreen, U., Hansen, B., Kiorboe, T., 1988. Food size spectra, ingestion and growth of copepod Acartia tonsa: implications for the determination of copepod production. Mar. Biol. 99, 341-352. 
Berman, T., Towensend, D.W., El Sayed, S.Z., Trees, C.C., Azov, Y., 1984. Optical transparency, chlorophyll and primary productivity in the Eastern Mediterranean near the Israeli coast. Oceanol. Acta 7, 367-372.

Børsheim, K.Y., Bratbak, G., 1987. Cell volume to cell carbon conversion factors for a bacterivorous Monas sp. enriched from seawater. Mar. Ecol. Prog. Ser. 36, 171-175.

Bradford-Grieve, J.M., Boyd, P.W., Chang, F.H., Chiswell, S., Hadfield, M., Hall, J.A., James, M.R., Nodder, S.D., Shushkina, E.A., 1999. Pelagic ecosystem structure and functioning in the Subtropical Front region east of New Zealand in austral winter and spring 1993. J. Plankton Res. 21 (3), 405-428.

Caron, D.A., Peele, E.R., Lim, E.L., Dennett, M.R., 1999. Picoplankton and nanoplankton and their trophic coupling in surface waters of the Sargasso Sea south of Bermuda. Limnol. Oceanogr. 44, 259-272.

Christaki, U., Van Wambeke, F., Dolan, J.R., 1999. Nanoflagellates (mixotrophs, heterotrophs and autotrophs) in the oligotrophic Eastern Mediterranean: standing stocks, bacterivory and relationships with bacterial production. Mar. Ecol. Prog. Ser. 181, 297-307.

Conan, P., Turley, C., Stutt, E., Pujo-Pay, M., Van Wambeke, F., 1999. Relationship between phytoplankton efficiency and the proportion of bacterial production to primary production in the Mediterranean Sea. Aquat. Microb. Ecol. 17 (2), 131144.

Dam, H.G., Peterson, W.T., 1988. The effect of temperature on the gut clearance rate constant of planktonic copepods. J. Exp. Mar. Biol. Ecol. 123, 1-14.

Deibel, D., Lee, S.H., 1992. Retention efficiency of sub-micrometer particles by the pharyngeal filter of the pelagic tunicate Oikopleura vanhoeffeni. Mar. Ecol. Prog. Ser. 81, 25-30.

Dolan, J.R., Vidussi, F., Claustre, H., 1999. Planktonic ciliates in the Mediterranean Sea: longitudinal trends. Deep-Sea Res., Part I 46, 2025-2039.

Egloff, D.A., Fofonoff, P.W., Onbe, T., 1997. Reproductive biology of marine cladocerans. Adv. Mar. Biol. 31, 79-167.

Fasham, M.J., Boyd, P.W., Savidge, G., 1999. Modelling the relative contributions of autotrophs and heterotrophs to carbon flow at a Lagrangian JGOFS station in the Northeast Atlantic: the importance of DOC. Limnol. Oceanogr. 44, 80-94.

Fernàndez, M., Bianchi, M., Van Wambeke, F., 1994. Bacterial biomass, heterotrophic production and utilisation of dissolved organic matter photosynthetically produced in the Almeria-Oran front. J. Mar. Syst. 5, 313-325.

Fortier, L., Le Fevre, J., Legendre, L., 1994. Export of biogenic carbon to fish and to deep ocean: the role of large planktonic microphages. J. Plankton Res. 16 (7), 809-839.

Gorsky, G., 1989. Aspects de la biologie de l'appendiculaire Oikopleura dioica Fol 1872 (Chordata, Tunicata). Oceanis 15 (1), $39-49$.

Gorsky, G., Dallot, S., Sardou, J., Fenaux, R., Carre, C., Palazzoli, I., 1988. C and N composition of some northwestern Mediterranean zooplankton and micronekton species. J. Exp. Mar. Biol. Ecol. 124, 133-144.

Gotsis-Skretas, O., Pagou, K., Moraitou-Apostolopoulou, M., Ignatiades, L., 1999. Seasonal, horizontal and vertical variability in primary production and standing stocks of phytoplankton and zooplankton in the Cretan Sea and the Straits of the Cretan Arc (March 1994-January 1995). Prog. Oceanogr. 44, 625-649.

Hansen, P.J., Bjornsen, P.K., Hansen, B., 1997. Zooplankton grazing and growth: scaling within the $2-2000 \mu \mathrm{m}$ body size range. Limnol. Oceanogr. 42, 687-704.

Hernandez-Becerril, D.U., 1987. Vertical distribution of phytoplankton in the Central and Northern part of the Gulf of California (June 1982). PS.Z.N.I. Mar. Ecol. 8 (3), 237-251.

Holm-Hansen, O., Lorenzen, C.J., Hormes, R.N., Strickland, J.D.H., 1965. Fluorometric determination of chlorophyll. J. Cons., Cons. Perm. Int. Explor. Mer. 30, 3-15.

Hopcroft, R.R., Roff, J.C., 1995. Zooplankton growth rates: extraordinary production by the larvacean Oikopleura dioica in tropical waters. J. Plankton Res. 17, 205-220.

Hopcroft, R.R., Roff, J.C., Lombard, D., 1998. Production of tropical copepods in Kingston Harbour, Jamaica: the importance of small species. Mar. Biol. 130, 93-604.

Huang, B., Hong, H., Wang, H., 1999. Size-fractionated primary productivity and the phytoplankton-bacteria relationship in the Taiwan strait. Mar. Ecol. Prog. Ser. 183, 29-38.

Ignatiades, L., 1998. The productive and optical status of the oligotrophic waters of the Southern Aegean Sea (Cretan Sea), Eastern Mediterranean. J. Plankton Res. 20 (5), 985-995.

Kiorboe, T., Mohlenberg, F., Hamburger, K., 1985. Bioenergetics of the planktonic copepod Acartia tonsa: relation between feeding, egg production and composition of specific dynamic action. Mar. Ecol. Prog. Ser. 26, 85-97.

Kirchman, D.L., 1993. Leucine incorporation as a measure of biomass production by heterotrophic bacteria. In: Kemp, P.F., Sherr, B.F., Sherr, E.B., Cole, J.J. (Eds.), Handbook of Methods in Aquatic Microbial Ecology. Lewis Publishers, Ann Arbor, pp. $509-512$.

Krom, M.D., Kress, N., Brenner, S., Gordon, S., 1991. Phosphorus limitation of primary productivity in the eastern Mediterranean Sea. Limnol. Oceanogr. 36, 24-432.

Krom, M.D., Brenner, S., Kress, N., Neori, A., Gordon, I.L., 1993. Nutrient distribution during an annual cycle across a warm-core eddy from the E. Mediterranean Sea. Deep-Sea Res. 40, 805825.

Kuosa, H., Kivi, K., 1989. Bacteria and heterotrophic flagellates in the pelagic carbon cycles in the northern Baltic Sea. Mar. Ecol. Prog. Ser. 53, 93-100.

Lee, S., Fuhrman, J.A., 1987. Relationships between biovolume and biomass of naturally derived marine bacterioplankton. Appl. Environ. Microbiol. 53, 1298-1303.

Legendre, L., Rassoulzadegan, F., 1995. Plankton and nutrient dynamics in marine waters. Ophelia 41, 153-172.

Levinsen, H., Nielsen, T.G., Hansen, B.W., 1999. Plankton community structure and carbon cycling on the western coast of Greenland during the stratified summer situation: II. Heterotrophic dinoflagellates and ciliates. Mar. Ecol. Prog. Ser. 16, $217-$ 232.

Lykousis, V., Chronis, G., Tselepides, A., Theocharis, A., Price, B., Ignadiades, L., Siokou-Frangou, I., Stavrakakis, S., Van Wambeke, F., Danovaro, R., Duineveld, G., Georgopoulos, D., Souvermezoglou, A., 2002. Major outputs of the recent multi- 
disciplinary biogeochemical researches in the Aegean Sea. J. Mar. Syst. 33-34, 313-334.

Mackas, D.L., Bohrer, R., 1976. Fluorescence analysis of zooplankton gut contents and an investigation of diel feeding patterns. J. Exp. Mar. Biol. Ecol. 25, 77-85.

Malone, T.C., Pike, S., Conley, D.L., 1993. Transient variations in phytoplankton productivity at the JGOFS Bermuda time series station. Deep-Sea Res. 40, 903-924.

Mazzocchi, M.G., Christou, E., Fragopoulu, N., Siokou-Frangou, I., 1997. Mesozooplankton distribution from Sicily to Cyprus (Eastern Mediterranean): I. General aspects. Oceanol. Acta 20 (3), $521-535$.

Morales, C.E., Bautista, B., Harris, R.P., 1990. Estimates of ingestion in copepod assemblages: gut fluorescence in relation to body size. In: Barnes, M., Gibson, R.N. (Eds.), Trophic Relationships in the Marine Environment. Univ. Press, Aberdeen, pp. $565-577$.

Mullin, N.J.B., Riley, J.P., 1955. The colorimetric determination of silicate with special reference to sea and natural waters. Anal. Chim. Acta 12, 162-176.

Murphy, J., Riley, J.P., 1962. A modified solution method for determination of phosphate in natural waters. Anal. Chim. Acta 27, $31-36$.

Nielsen, T.G., Hansen, B., 1995. Plankton community structure and carbon cycling on the western coast of Greenland during and after the sedimentation of a diatom bloom. Mar. Ecol. Prog. Ser. $125,239-257$.

Nielsen, T.G., Hansen, B.W., 1999. Plankton community structure and carbon cycling on the western coast of Greenland during the stratified summer situation: I. Hydrography, phytoplankton and bacterioplankton. Mar. Ecol. Progr. Ser. 16, 205-216.

Nielsen, T.G., Kiorboe, T., 1991. Effects of a storm on the structure of the pelagic food web with special emphasis on planktonic ciliates. J. Plankton Res. 13 (1), 35-51.

Nielsen, T.G., Lokkegaard, B., Richardson, K., Pedersen, F.B., Hansen, L., 1993. Structure of plankton communities in the Dogger Bank area (North Sea) during a stratified situation. Mar. Ecol. Prog. Ser. 95, 115-131.

Pace, M.L., McManus, G.B., Findlay, S.E.G., 1990. Planktonic community structure determines the fate of bacterial production in a temperate lake. Limnol. Oceanogr. 35, 795-808.

Pedros-Alio, C., Calderon-Paz, J.I., Guixa-Boixereu, N., Estrada, M., Gasol, J.M., 1999. Bacterioplankton and phytoplankton biomass and production during summer stratification in the northwestern Mediterranean Sea. Deep-Sea Res., Part I 46, 985-1019.

Peterson, W.T., 1988. Rates of egg production by the copepod Calanus marshallae in the laboratory and in the sea off Oregon, USA. Mar. Ecol. Prog. Ser. 47, 229-237.

Pitta, P., Giannakourou, A., 2000. Planktonic ciliates in the oligotrophic Eastern Mediterranean: vertical, spatial distribution and mixotrophy. Mar. Ecol. Prog. Ser. 194, 269-282.

Polat, C., Tugrul, S., 1996. Chemical exchange between the Mediterranean and the Black Sea via the Turkish straits. Dynamics of Mediterranean Straits and Channels. CIESM Science Series no. 2. Bull. Inst. Oceanogr. Monaco, no. special 17, pp. 167186.

Psarra, S., Tselepides, A., Ignatiades, L., 2000. Primary productiv- ity in the oligotrophic Cretan Sea (NE Mediterranean): seasonal and interannual variability. Prog. Oceanogr. 46 (2-4), $187-$ 204.

Putt, M., Stoecker, D.K., 1989. An experimentally determined carbon volume ratio for marine oligotrichous ciliates from estuarine and coastal waters. Limnol. Oceanogr. 34, 1097-1103.

Richardson, K., Nielsen, T.G., Pedersen, F.B., Heilmann, J.P., Lokkegaard, B., Kaas, H., 1998. Spatial heterogeneity in the structure of the planktonic food web in the North Sea. Mar. Ecol. Prog. Ser. 168, 197-211.

Robarts, R.D., Zohary, T., Waiser, M.J., Yacobi, Y.Z., 1996. Bacterial abundance, biomass, and production in relation to phytoplankton biomass in the Levantine Basin of the southeastern Mediterranean Sea. Mar. Ecol. Prog. Ser. 137, 273-281.

Roman, M.R., Caron, D.A., Kremer, P., Lessard, E.J., Madin, L.P., Malone, T.C., Napp, J.M., Peele, E.R., Youngbluth, M.J., 1995. Spatial and temporal changes in the partitioning of organic carbon in the planktonic community of the Sargasso sea off Bermuda. Deep-Sea Res., Part I 42 (6), 973-992.

Sempere, R., Panagiotopoulos, C., Lafont, R., Marroni, B., Van Wambeke, F., 2002. Total organic carbon dynamics in the Aegean Sea. J. Mar. Syst. 33-34, 355-364 (this issue).

Sherr, E., Sherr, B., 1988. Role of microbes in pelagic food webs: a revised concept. Limnol. Oceanogr. 33 (5), $1225-$ 1227.

Shinn, M.B., 1941. A colorimetric method for the determination of nitrite. Ind. Eng. Chem. 13, 33-35.

Siokou-Frangou, I., Zervoudaki, S., Christou, E.D., manuscript in preparation. Mesozooplankton community structure and distribution in the Aegean Sea.

Souvermezoglou, E., Hatzigeorgiou, E., Pampidis, I., Siapsali, K., 1992. Distribution and seasonal variability of nutrients and dissolved oxygen in the northeastern Ionian Sea. Oceanol. Acta 15 (6), 585-594.

Steemann-Nielsen, E., 1952. The use of radioactive carbon ${ }^{14} \mathrm{C}$ for measuring organic production in the sea. J. Cons. Exp. Mer. Mediterr. 18, 117-140.

Stergiou, K.I., Christou, E.D., Georgopoulos, D., Zenetos, A., Souvermezoglou, C., 1997. The Hellenic seas: physics, chemistry, biology and fisheries. Ocean. Mar. Biol. Annu. Rev. 35, 415538.

Strickland, J.D.H., Parsons, T.R., 1968. A practical handbook of sea water analysis. Bull. Fish. Res. Board Can. 167, 310 pp.

Theocharis, A., Georgopoulos, D., 1993. Dense water formation over the Samothraki and Limnos plateaux in the North Aegean Sea (Eastern Mediterranean Sea). Cont. Shelf Res. 13 (8/9), 919-939.

Theocharis, A., Balopoulos, E., Kioroglou, S., Kontoyiannis, H., Iona, A., 1999. A synthesis of the circulation and hydrography of the South Aegean Sea and the Straits of the Cretan Arc. Prog. Oceanogr. 44, 469-509.

Turley, C.M., Bianchi, M., Christaki, U., Conan, P., Harris, J.R., Psarra, S., Ruddy, G., Stutt, E.P., Tselepides, A., Van Wambeke, F., 2000. Relationship between primary producers and the bacteria in an oligotrophic sea-the Mediterranean and biochemical implications. Mar. Ecol. Progr. Ser. 193, 11-18.

Turner, J.T., Tester, P.A., Ferguson, R.L., 1988. The marine clado- 
ceran Penilia avirostris and the "microbial loop" of pelagic food webs. Limnol. Oceanogr. 33, 245-255.

Utermohl, H., 1958. Zur vervollkommnung der quantitativen phytoplankton methodik. Mitt. Int. Ver. fur Theor. Anderwandte Limnol. 9, 1-38.

Van Wambeke, V.F., Christaki, U., Gaudy, R., 1996. Carbon fluxes from the microbial food web to mesozooplankton. An approach in the surface layer of a pelagic area (NW Mediterranean Sea). Oceanol. Acta 19, 57-66.

Van Wambeke, F., Christaki, U., Bianchi, M., Psarra, S., Tselepides, A., 2000. Heterotrophic bacterial production in the Cretan Sea (NE Mediterranean). Prog. Oceanogr. Ser. 45, 205-216.

Van Wambeke, F., Heussner, S., Diaz, F., Raimbault, P., Conan, P., 2002. Small-scale variability in the coupling/uncoupling of bacteria, phytoplankton and organic carbon fluxes along the con- tinental margin of the Gulf of Lions, Northwestern Mediterranean Sea. J. Mar. Syst. 33-34, 411-429 (this issue).

Yoro, S., Sempéré, R., Turley, C., Unanue, M., Durrieu de Madron, X., Bianchi, M., 1997. Cross-slope variations of organic carbon and bacteria in the Gulf of Lions in relation to water dynamics (northwestern Mediterranean). Mar. Ecol. Prog. Ser. 161, $255-264$.

Zervakis, V., Georgopoulos, D., Drakopoulos, P.G., 2000. The role of the North Aegean in triggering the recent Eastern Mediterranean climatic changes. J. Geophys. Res. 105 (C11), 2610326116.

Zohary, T., Robarts, R.D., 1998. Experimental study of microbial Plimitation in the eastern Mediterranean. Limnol. Oceanogr. 43, $387-395$. 